\title{
INVESTIGATION OF CLIMATE VULNERABILITY OF DOMESTIC NATURAL AND ARTIFICIAL ECOSYSTEMS
}

\section{HAZAI TERMÉSZETES ÉS MESTERSÉGES ÖKOSZISZTÉMÁK KLIIMAÉRZÉKENYSÉGÉNEK VIZSGÁLATA}

\author{
FÖLDI, László; HALÁSZ, László \\ (ORCID: 0000-0001-7575-7188); (ORCID: 0000-0002-8257-4459) \\ foldi.laszlo@uni-nke.hu; laszlohalasz1@t-online.hu
}

\begin{abstract}
The climate change, the increase of average temperature, the changing of precipitation and its distribution, the increase of frequency of extreme weather events have significant effects on all ecosystems. The most vulnerable are the natural ecosystems. In case of forest the climate change causes large changes in the spatial distribution of tree species and that these changes may be associated with significant tree mortality, forest decline, and loss of forest cover. The climate change affects the properties of soil and because the soil is Hungary's natural water reservoir of the largest water storage capacity. thus is important task to keep its properties. In the Hungarian agriculture is the drought that causes the highest losses, and it is followed by frost damage and water damage. The adaptation and mitigation were discussed on the basis of the National Forest Strategy and the Second National Climate Change Strategy 2014-25 with an Outlook until 2050.
\end{abstract}

Keywords: Climate change, ecosystems, forests, soil, agriculture, adaptation and mitigation.

\begin{abstract}
Absztrakt
$A z$ éghajlatváltozás, a növekvő átlaghömérséklet, a változó csapadék mennyiség és eloszlás, a gyakoribb extrém időjárási események jelentős hatást gyakorolnak a teljes ökoszisztémára. Az ökoszisztéma legsérülékenyebb részei a természetes ökoszisztémák. Erdők esetében a klímaváltozás nagy változást okoz a fafajok elterjedésében és ez együtt jár a fa elhalások növekedésével, erdörészek pusztulásával. Az éghajlatváltozás befolyásolja a talaj tulajdonságait mivel Magyarországon a talaj a legnagyobb víztároló, a talaj eredeti tulajdonságainak megőrzése fontos feladat. $A$ magyar mezőgazdaságban a szárazság okozza a legnagyobb károkat, amit a fagyok illetve víz okozta károk követnek. Az adaptációt és alkalmazkodást a „Nemzeti Erdőstratégia” és a „Második Nemzeti Éghajlatváltozási Stratégia 2014-25, 2050-ig szóló elöretekintéssel" címü dokumentumok alapján mutatjuk be.
\end{abstract}

Kulcsszavak:

Éghajlatváltozás, ökoszisztémák, erdők, talaj, mezőgazdaság, adaptáció és mitigáció. 


\section{INTRODUCTION}

The climate change is a fact today. The atmosphere and ocean have warmed, the amounts of snow and ice have diminished, and sea level has risen. The annual mean temperature will increase by $0.5{ }^{\circ} \mathrm{C}$ until the end of the twenty-first century in the northern hemisphere, if the composition of the atmosphere remains constant. However, the temperature may increase by 1.5-4.0 ${ }^{\circ} \mathrm{C}$ if the present economic activity maintained [1]. In Hungary, in addition to the increasing average temperatures, lower average rates of annual precipitation and a rearrangement of the distribution of precipitation (more precipitation in winter and less in summer), as well as an increase in the frequency and intensity of extreme weather events are foreseen. Natural vegetation is a dynamic component of the climate system. Not only the distribution of vegetation is determined and limited by temperature and precipitation conditions, but also vegetation has an effect on the biogeophysical properties of the land surface, which plays a key role in determination of weather and climate. Changes of the land cover due to climatic conditions and human influence feed back to the atmosphere, lead to the enhancement or reduction of the original climate change signal.

Causal attribution of recent biological trends to climate change is complicated because nonclimatic influences dominate local, short-term biological changes. Any underlying signal from climate change is likely to be revealed by analyses that seek systematic trends across diverse species and geographic regions. According to diverse analyses to more than 1,700 species, and show that recent biological trends match climate change predictions. Global meta-analyses documented significant range shifts averaging $6.1 \mathrm{~km}$ per decade towards the poles (or meters per decade upward), and significant mean advancement of spring events by 2.3 days per decade [2].

\section{THE EFFECTS OF CLIMATE CHANGE ON NATURAL ECOSYSTEMS}

Hungary is one of the most vulnerable countries of the world in respect to the impacts of climate change on natural ecosystems and on biodiversity. While in other countries only some area fall into category of high ecological vulnerability, in Hungary there are hardly any places that do not fall to this. In Europe situations worse than in Hungary are found only in Belgium. The process of the rearrangement of ecosystems due to the changes of the climate results in vulnerable simplified communities and this opens a door to the immigration of the usually easily spreading invasive species. [3]

Upon the climate's warming up a bit more than a few degrees the natural zones of the ecosystems will shift to such an extent, which will not allow the staying of the communities in their present form and on their present site. This situation is further aggravated when the transition is not gradual but rapid. If the climate changes substantially then the task of nature conservation organs must, in addition to their efforts of preservation, get prepared to accept some changes and the relating natural processes (migration of species, local extinction of some other ones and settlement of newly immigrated ones).

In Hungary the natural ecosystems will be subject to the following more important changes upon the impact of climate changes [4]:

- Shifting of the border of vegetation zones.

- Rearrangement of biotic communities and food webs.

- Disappearance of native species, especially in isolated habitats.

- Decrease of biodiversity on the long term.

- Spreading of invasive species, appearance of new invasive species (spreading of pests, insects and weeds).

- Habitats become drier (wetland habitats disappear; sandy-dune habitats will be desertified). 
- Functions of ecosystems will be damaged.

- Drying of soils, damage to the biological processes of the soils.

- Fire accidents become more frequent.

\section{THE EFFECTS OF CLIMATE CHANGE ON FORESTS}

Precipitation and temperature are the ultimate drivers of vegetation distribution on earth. Globally, zonal forests are generally found in areas where annual precipitation exceeds evapotranspiration, and thus forests are both dependent from and the sources of surface water sources. Water use by temperate forests is generally less than $700 \mathrm{~mm}$ during the growing season, suggesting that ecosystem water use (tree transpiration + evaporation) is limited by energy and water availability [5]. Most published projections of potential impacts of climate change on forest ecosystems are based on the following premises [6]:

- (1) climate will be warmer and temperature will increase rapidly,

- (2) climate will be drier in continental regions because of increased evapotranspiration, and

- (3) climate is the only factor controlling tree species range limits.

The latter premise is implicit in all projections that use correlations between current or past tree distribution and climate. Based on these premises, most published projections of forest responses to climate change indicate that there will be large changes in the spatial distribution of tree species and that these changes may be associated with significant tree mortality, forest decline, and loss of forest cover. Tree mortality will be associated with climate-induced reductions in growth.

Whereas the upper forest limit is determined by the temperature conditions (called thermal limit), on the lower margin, presence of forests is primary limited by the climatic aridity [7]. Here, extent of the climatically suitable area of the certain tree species is determined by the frequency, severity and duration of droughts rather than by the climatic means. Small increase of the frequency of extremes can lead to drastic effects (growth decline or mortality of forests) in these regions [8]. Whereas the upper forest limit is determined by the temperature conditions (called thermal limit), on the lower margin, presence of forests is primary limited by the climatic aridity [7].

Hungary has a special ecologic position on the border zone of closed forests and forest steppe (lower forest limit), which is especially vulnerable. The increase of drought frequency can lead to decrease of the forest cover across this region. This phenomenon is not typical in humid areas of the world. The climate change in temperature and precipitation will have an impact on the growth and yield of forests, which in turn will affect the composition of tree species and the generation rates of organic matter.

This variability will delineate the area of propagation of various tree species and with this the generation rates of organic matter of the forest ecosystems.

Here, extent of the climatically suitable area of the certain tree species is determined by the frequency, severity and duration of droughts rather than by the climatic means. Small increase of the frequency of extremes can lead to drastic effects (growth decline or mortality of forests) in these regions [8].

Hungary has special climatic conditions regarding forest vegetation zonation. Here, many of the zonal tree species have their lower limit of distribution, which are especially sensitive and vulnerable to the consecutive and severe dry periods. As the result of the predicted climate change, not only the ecological circumstances but the profitability of forested areas will also change in the future in Hungary. 
Compared to grasslands or short-cycle crops, forests have large above-ground biomass and deeper roots, therefore can use more water and can capture larger amounts of carbon through photosynthesis as carbon and water cycles are highly coupled [9].

In the last century, large-scale reforestation programs changed the land cover of the Hungarian Great Plain, with the aim to improve not only timber supply but also the regional climate and hydrology of the largely treeless landscape. For example, on the Danube-Tisza Sand Plateau, a region of 828 thousand ha, forest cover increased in four decades from $5 \%$ to $26 \%$. Presently game overpopulation causes serious damages to forests and this damage is 2 10 fold larger than that of the year 1971. The game stock might amplify the impacts of climate changes and therefore the populations of deer and wild boar should be decreased to 80,000 and 56,000 respectively, while it is also justifiable to decrease the fallow deer- and mouflon population of 20,000. The small game stock of Hungary is of good quality but its population is smaller than desirable (the size of predator population causes serious problems). The balance in agriculture, forest and game management should be achieved by means of the following elements:

- game population and the ecosystem supporting capability of the habitats;

- the benefits and damages of games, so as to decrease the latter;

- in among the interests of game, hunter, forest, nature, nature conservation and environmental protection, agriculture, country-side development and traffic.

\section{THE EFFECTS OF CLIMATE CHANGE ON SOIL}

In Hungary fertile soil of arable land is one of the most valuable, potentially renewable, natural resources. Rational and sustainable use and the protection of the conditions and the multiple functions of this resource are the basic tasks of the protection of the environment and of the production of biomass and thus these are the basic elements of sustainable development and of the common interest of the society. In terms of climate policy and within this in terms of the adaptation strategies the most important function of the soil is its water household property because the soil is Hungary's natural water reservoir of the largest water storage capacity.

Consequently, the preservation and improvement of the water holding capacity of the soils are the important factors of the adaptation to the changes of the climate, along with the use of proper soil cultivation and conservation techniques, including the use of organic manure. The value of the soil is defined more and more by the water resource it contains instead of other parameters of soil fertility.

Water erosion may occur in increasingly extreme forms due to the changes of the climate. This means that due to increasing forces of rainfall and of runoff water endangers the soil and objective oriented water management techniques are required for counteracting erosion. Overall data indicate that the erosion damages are observable on 2.3 million hectares (that is about $25 \%$ of the country's territory). Protection against erosion enhances the preservation of the quality and quantity of the soil. Therefore, the mitigation of the harmful effects of water erosion also belongs to the means of adaptation strategies, actually of the preventive strategies.

Protective soil cultivation, appropriate crop rotation and perennial sods play important role in soil conservation. Prevention involves three types of tasks [4]:

- Soil cultivation techniques, which enhance the infiltration of precipitation water into the soil.

- Coverage of the soil surface (mulching) in periods out of the growing season in order to avoid erosion, maintenance of soil texture and the preservation of soil properties that enhance cultivation.

- Provision of obstacles to runoff water, keeping precipitation where it falls in a growing season, with various tillage techniques and soil formations (ridges and protective strips formed with stubble worked into the soil). 
The characteristics of soil usage aimed at decreasing the damages of the changing climate can be summarized as follows [4]:

- Protection of the favorable physical and biological conditions of the soil as an environmental element.

- Protection and improvement of the qualitative properties of the soil (organic content, crumbly and loose structure, water content) with appropriate cultivation techniques.

- Avoidance of soil use, which results in the degradation of the soil (compaction, dustand clod formation) and, when damage occurs, the carrying out of measures that improves the degraded soil.

- Keeping the favorable biological effects of the crop sequence with protective cultivation and the improving of the favorable effect of protective cultivation with the biological effects of the crop.

- Forming the state of the soil surface and the root zone, in a given year, as required by the impacts of the climate (damage mitigation and increasing the security of harvest).

- Preserving the useful biological properties of the soil, by the harmony of the appropriate sequence of crop and nutrient supply.

- Integrated plant protection with soil conservation techniques, mulching and appropriate crop rotation.

Soil represents a considerable part of the natural resources, consequently, rational land use and soil management - guaranteeing normal soil functions - are important elements of sustainable development, having special importance both in the national economy (rural development, agriculture) and in environment protection. Soils are the most important conditionally renewable natural resources in the Carpathian Basin, with three specific/unique characteristics:

More than half of the arable lands of Hungary are affected by groundwater flooding, especially in the deep-lying Great Plains, Little Plain and the Dunamellék (Danube Region). It should be noted that storing water in the soil, the fight against groundwater floods and droughts and a transformation of soil cultivation also contribute to the prevention of floods. Areas that are deep-lying, regularly affected by groundwater floods and have defective soil should be withdrawn from field cultivation by changing the form of cultivation or the form of land use. Aid systems should be adjusted to the optimized forms of landscape, area and land use of multiple aspects [10].

Ice rains are a significant risk factor in agriculture. The soil generator hail suppression technology significantly reduced the harmful effects of hails. As regards earlier blooming, especially in the case of fruit trees, frost damage is the largest troublemaker. The various protection solutions are to reduce and eliminate extreme weather hazards: ice web, hail suppressor with soil generator, paraffin cans, irrigation against frost, foil cover.

Water reserves can considerably enhance agricultural adaptability, the establishment of multipurpose reservoirs, their use for irrigation, extension of lake fisheries, increase of biodiversity, long term integration of nature conservation and agriculture, utilization of areas exposed to floods and protected with summer dams with flood-resistant, moreover: flood requiring, forms of cultivation. Irrigation should be encouraged in connection with the restoration of previous systems and the creation of new ones, first of all on good production locations and valuable plantations, in case of production in foil tents and greenhouses, for certain arable crops and technological phases (irrigation for germination). Irrigation can be realistic for such forms of production that produce high added value, and can be considered as a local solution only. In most of our regions, the solution is the planning and harmonization of the water demand, establishment of water regulation of water retention and the landscape 
management systems based thereon, facilitation of infiltration and involvement of cultures requiring less water into cultivation. In case of irrigation, it is advisable to consider the increasing price of food products and irrigation water. It is worth applying already forgotten traditional methods to irrigate gardens around houses, spray trees, wash clothes and clean such as the capturing, storage of the precipitation using cisterns, tanks, tubs and barrels. The application of these methods is possible on the small scale only, having regard to the fact that rainwater can be captured and used to a limited extent only [11].

\section{THE EFFECTS OF CLIMATE CHANGE ON AGRICULTURE}

Decreases in total agricultural land area are projected under all the IPCC Special Report on Emissions Scenarios (SRES) storylines [12], but are most marked in Southern Europe. However, increases in productivity may not necessarily lead to overall increases in carbon storage since climate change could also increase the length of the season when respiration occurs [13]. In Northern Europe, the suitability and productivity of crops is likely to increase and extend northwards, especially for cereals and cool season seed crops. Crops now prevalent mostly in Southern Europe such as maize, sunflower and soybeans could also become viable further north and at higher altitudes [14]. Here, yields could increase by as much as $30 \%$ by the 2050s, dependent on crop [14]. In Central and Eastern Europe, climate change and technological advances will likely increase productivity, leading to replacement of fodder crops with cash crops [15]. Decreases in total agricultural land area are projected under all the IPCC Special Report on Emissions Scenarios (SRES) storylines [12], but are most marked in Southern Europe. However, increases in productivity may not necessarily lead to overall increases in carbon storage since climate change could also increase the length of the season when respiration occurs [13]. In Northern Europe, the suitability and productivity of crops is likely to increase and extend northwards, especially for cereals and cool season seed crops. Crops now prevalent mostly in Southern Europe such as maize, sunflower and soybeans could also become viable further north and at higher altitudes. Here, yields could increase by as much as $30 \%$ by the 2050s, dependent on crop [14]. In Central and Eastern Europe, climate change and technological advances will likely increase productivity, leading to replacement of fodder crops with cash crops [15].

In Hungary, agriculture is the sector which is most vulnerable to the climate change. The effects of climate change are differentiated in time and space, and cause different damage, subject to, amongst others, the specificities of nature, land use, agro-techniques. Amongst the elemental types of damage, it is the drought that causes the highest lost in the long run in Hungary, and it is followed by frost damage and water damage. Considering the fact that we have to expect an increasing average summer temperature and a decreasing summer precipitation, it can be concluded that the largest challenge agriculture faces is the increase of the chances of drought. The vulnerability of various forms of land use, including arable crop production, to climate change were studied in detail in the National Adaptation Geoinformation System to agriculture (AGRAGIS) project closed in 2016 [16].

In addition to the process of warming and drying, unexpected meteorological phenomena can also cause significant damage. The followings can be mentioned among weather and climate-related agricultural risks [16]:

- flood, groundwater flood;

- drought;

- flood-like rains, mud avalanches, landslides, soil erosion;

- wind storms, wind erosion;

- hails, freezing rains, fog, hoarfrost;

- snowdrift, snow barriers;

- days with heat, heatwaves, more intense UVB radiation; 
- early and late frost, frost damage;

- forest, wildfires, stubble fires;

- appearance of new pathogens, pests and weeds; increasing hazardousness of certain pests that are indigenous to Hungary but have been only of minor significance so far;

- yield reduction, indirectly, due to the increasing ozone concentration.

The basis for agricultural adaptation, and a fundamental precondition to agricultural production, is water and fertile soil. The basis of adaptive intervention is adjusting land use to the changing ecological conditions. The fundamental condition for agricultural production is water, the retention of natural precipitation in the microregional water cycle, and facilitating its filtration into the soil. The fertile soil is the largest water reservoir in Hungary, its preservation and utilization, and the supplying of missing water, is of key importance.

Retention, utilization of water and precipitation coming on streams and irrigation do not only lay the foundation for yield security but also for the effective combatting of droughts, groundwater flood, floods and weather anomalies. Our use of land and the agricultural production structure must be revised and adjusted to the changing conditions, thus decreasing irrational, intensive, wasting and unsustainable activities. The solution for areas that are deeplying, affected by groundwater floods and have a heavy soil could be a modern technique and technology and soil cultivation.

It has already become typical of Hungary, that a single year can see severe river floods, groundwater floods, drought and frost damage, meaning that the expected warming and drying raises the serious question of food security. Critical years can see our dependence on food import increasing, while the demand of countries having scarce natural resource to produce food, meaning that the price of imported foodstuffs will increase sharply. Risks of food supply can be reduced by reinforcing the adaptability of Hungarian crop production and its consequences can be mitigated.

Subject to the animal species and the form of husbandry, animal husbandry can react differently to the expected effects of climate change. Intensive animal husbandry is the most vulnerable. Cattle, pigs and poultry in intensive livestock farming are very sensitive and react with yield decline to certain shocks. Certain traditional animal breeds (such as the Hungarian grey cattle, mangalica, the Racka sheep, Hungarian chicken) are more adaptive thanks to their genetics and their extensive farming technology, the productivity of these animal breeds does not reach that of intensive breeds. The increasing water and shading demand of animals should also be taken into consideration. During the improvement of animal breeds, consideration of characteristics better tolerating the expected effects of climate change and the changes of farming conditions according to the expected effects come more and more into the foreground besides performance and quality, and the preparation of animal health for the effects of climate change will play an important role.

The most important question and greatest challenge of the adaptation to climate change in livestock farming will be the predictable supplying of feed and wager (management of droughts, floods and extreme weather phenomena in feed production and water management). It's important that plants and animals kept in Hungary are of such species composition that is more easily adapted to expected climate change. The agro ecological conditions of Hungary would allow for a varied and balanced product structure, still, the agricultural production structure has become disrupted in terms of the two main parts, crop production and livestock farming, at the detriment of the latter. Within the domain of livestock farming, cattle husbandry is in the most critical situation, due to the difficulties of the European, including the Hungarian, milk market. A significant increase of the cattle stock would be possible if our GHG emission would increase as little as possible. 


\section{THE POSSIBILITY OF MITIGATION AND ADAPTATION}

Forestry tasks related to climatic adaptation are included in the National Forest Strategy (20162030) [17], during the implementation of which it would be practical to consider the following action lines.

Short-term action lines:

- According to the National Afforestation Program, forests must increase in area, subject to the changing conditions at production locations - applying the right tree species, primarily indigenous, and Hungarian reproductive materials.

- The reduction of fire risk requires measures to prevent forest fires, and the elimination of the most flammable trees from the most flammable areas.

- It is recommended to study the future development of the effect of climate change on forests, forest habitats and forest microclimate, applying a geo-information model considering the results of Earth observation and remote sensing to display the possible scenarios of the changing climatic zones, the possible extent of the changes in the zonal forest coverage, the effect on soil types, the expected migration of forest forming tree-species.

- Preparation of climate vulnerability analyses, in connection with the NAGiS, capable of the quantified description of the expected changes and adaptability with indicators as regards the species and production areas applied in forestry.

Mid-term action lines

- Development of models for foresters, in consideration of the requirements of long term, sustainable forestry, specialties of 30-150 years long turns of logging, the opportunities of foresters.

- Compilation of forest planning manuals for tree species selection and forest growing, and considering the effects of climate change. Elaboration and operation of a decision supporting system to help forestry and forest planning, while also considering the effects of climate change.

- Monitoring, adaptive management and, if necessary, replacement of the tree stock of the forest areas of vulnerable regions, based on Earth observation data and remote sensing, corresponding revision of the 10-year district forest plan, timely restoration of forest areas damaged by natural disasters.

- Water regulation of forest areas, improvement of the water retention capacity of forests, improvement of their water supply.

- Facilitation of the adaptation of trees with a long growing season to climate change within the framework of forestry, applying the supported form of migration.

- Spreading of such forestry technologies of sustainable forestry that increase the stability of forests (increased mixture) against the effects of climate change, including the reduction of the risk of drought, forest fires, pests, storms. The aspects of climate change must be gradually integrated into the system of forest planning, including the definition of the growing site and the selection of the tree species.

- Reinforcement and development of the forestry monitoring system, with special regard to the increasing utilization of remote sensing, the integrated assessment of information acquired with remote sensing and Earth observation, and their optimized utilization.

- Maintenance of a sustainable stock of big game in the long run, not hampering seminatural forest regeneration methods. 


\section{Long-term action lines}

- Comprehensive integration of climate change, as a boundary condition, into forestry policies, taking actual changes in the climate also into consideration.

- Application of semi-natural forestry methods that consider natural forest dynamics, the pace of climate change and its expected effects, including the gradual implementation of forestry methods resulting in continuous forest coverage in areas capable of doing that.

- Development of a form of forestry that ensures adaptation to climate change, in consideration of natural forest dynamics. The intervention pays special attention to achieving the highest possible level of afforestation, the selection of the right species, the increasing of the mixture of species and ensuring the opportunities of restoration.

- In the wooded steppe zones, gallery forests that close in low should be sustained at places where closed stocks cannot be sustained any longer.

- Preservation of local genetic resources, relying primarily on Hungarian genetic resources, by selecting the elements that best adapt to future production trends.

In 2013, Hungary released the Second National Climate Change Strategy 2014-25 with Outlook until 2050, which presented the consequences of climate change for Hungary and the measures necessary to address these impacts [18]. According to the report, Hungary will in particular be seriously affected by the expected climate change due to its geographical characteristics. This will apply particularly to the already disadvantaged regions of the country. The report also says that agriculture can expect longer dry periods, as already seen in recent years. It also recommends that the government should incorporate these developments into its policy measures.

Opportunities to mitigate agricultural damage caused by the climate change:

- establishment of a water-retaining water regulation and landscape management, sustainable irrigation;

- increasing biodiversity, growing multiple plant species together, creation of meadow-protecting forest belts with indigenous species (trees and shrubs: hawthorn, sloe, maple, other species according to the habitat concerned);

- improvement and introduction into production of plant breeds that can adapt well and can be grown securely;

- introduction of cultures that are varied, capable of self-protection and seminatural (fruit plantations, extensive orchards, systems of agroforestry);

- involvement of indigenous local species that are less sensitive to weather extremities into production;

- applying soil cultivation methods that imply less soil disturbance, applying mulching, composting and green manure;

- planting semi-natural biotopes, forest belts, turning pastures into groves,

- increase of green surfaces;

- cooling, ventilation of livestock buildings, shading around stalls;

- preparation of plant protection and animal health;

- general introduction of sustainable farming systems, with special regard to the spreading of ecological farming;

- increasing research activities to support the foregoing, supporting farmers with the necessary knowledge and advice.

The foundation for the adaptation strategy of agriculture and the precondition and essence of every other development is water: the balance should be made between the resources that are becoming scarce and are distributed less and less evenly, and the increasing demand. An 
appropriate use of landscape, aligning to the changing climatic and ecological conditions, must be established, and maintenance of the water demand at a reasonable level must be ensured. Special attention must be paid to landscape-level water resupplying, establishment of microregional water cycles, semi-natural water resupplying and water storage and the farming systems based on them. Landscape mosaicism must be increased, as it decreases landscape vulnerability. Water supply to crop production, livestock farming, processing and farmers, which align with the correctly chosen form of land use, must be ensured, first of all by facilitating, preserving the infiltration of natural precipitation into the soil, the reduction of evaporation, reasonable and efficient use, satisfying the water demand with various other solutions, irrigation, storage and consideration of surface, soil and stratum waters.

The most important element of the adaptation strategy of agricultural activities is the enforcement of sustainability, applying sustainable production systems and a sustainable way of farming. The second level has effects and responses related to sowings, plantations, livestock and the applied techniques and technologies (modern, water-efficient soil cultivation, transformation of production and sowing structure, application of indigenous, semi-indigenous and regional breeds that are less sensitive to extremities). It is important that the adaptation process does not only facilitate the attainment of sustainable development in environmental terms, but it should improve the capacity to retain the rural population as well.

The point of the adaptive utilization strategy is to utilize the entire biomass produced, as it comprises the security, in terms of quality and quantity of products and foodstuffs produced, feeding and energy supply as well. As laid down in the National Rural Strategy, the goal is to implement a form of agricultural production that is based on environmentally friendly development aspects.

\section{SUMMARY}

Hungary is one of the most vulnerable countries of the world in respect to the impacts of climate change on natural ecosystems and on biodiversity. The process of the rearrangement of ecosystems due to the changes of the climate results in vulnerable simplified communities and this opens a door to the immigration of the usually easily spreading invasive species.

In Hungary the foreseen potential changes of the climate will create warmer and drier weather conditions. The increasing dryness of the air and soil will be caused by the rise of temperature, mostly in the summer periods, and by the modification of the distribution of precipitation within the year. These will have an impact on the growth and yield of forests, which in turn will affect the composition of tree species and the generation rates of organic matter. In Hungary fertile soil of arable land is one of the most valuable, potentially renewable, natural resources. Rational and sustainable use and the protection of the conditions and the multiple functions of this resource are the basic tasks of the protection of the environment and of the production of biomass and thus these are the basic elements of sustainable development and of the common interest of the society. In terms of climate policy and within this in terms of the adaptation strategies the most important function of the soil is its water household property because the soil is Hungary's natural water reservoir of the largest water storage capacity.

Future projected trends in European agriculture include northward movement of crop suitability zones and increasing crop productivity in Northern Europe, but declining productivity and suitability in Southern Europe. This may be accompanied by a widening of water resource differences between the North and South, and an increase in extreme rainfall events and droughts. In Hungary, agriculture is the sector which is most vulnerable to the climate change. The effects of climate change are differentiated in time and space, and cause different damages. The basis for agricultural adaptation, and a fundamental precondition to agricultural production, is water and fertile soil. The basis of adaptive intervention is adjusting 
land use to the changing ecological conditions. The fundamental condition for agricultural production is water, the retention of natural precipitation in the microregional water cycle, and facilitating its filtration into the soil. Considering the adaptation and mitigation the National Forest Strategy and the Second National Climate Change Strategy are important. Forestry tasks related to climatic adaptation are included in the National Forest Strategy (2016-2030). In 2013, Hungary released the Second National Climate Change Strategy 2014-25 with Outlook until 2050, which presented the consequences of climate change for Hungary and the measures necessary to address these impacts.

\section{REFERENCES}

[1] Intergovernmental Panel on Climate Change (IPCC). 2007. Alcamo, J., J. M. Moreno, B. Nováky, M. Bindi, R. Corobov, R. J. N. Devoy, C. Giannakopoulos, E. Martin, J. E. Olesen, A. Shidenko, 2007. Europe. Climate Change 2007: Impacts, Adaptation and Vulnerability. Contribution of Working Group II to the Fourth Assessment Report of the Intergovernmental Panel on Climate Change. Parry M. L., O. F. Canziani, J. P. Palutikof, P. J. van der Linden and C. E. Hanson, (Eds.) Cambridge University Press, Cambridge, $\mathrm{UK}$.

[2] IPCC, 2014: Summary for Policymakers. In: Climate Change 2014: Mitigation of Climate Change. Contribution of Working Group III to the Fifth Assessment Report of the Intergovernmental Panel on Climate Change [Edenhofer, O., R. Pichs-Madruga, Y. Sokona, E. Farahani, S. Kadner, K. Seyboth, A. Adler, I. Baum, S. Brunner, P. Eickemeier, B. Kriemann, J. Savolainen, S. Schlomer, C. von Stechow, T. Zwickel and J.C. Minx (eds.)]. Cambridge University Press, Cambridge, United Kingdom and New York, NY, USA.

[3] Bakkenes, M., Alkemade, J. R. M., Ihle, F., Leemans, R., Latour, J. B.: Assessing effects of forecasted climate change on the diversity and distribution of European higher plants for 2050. Global Change Biology 8,(2002), 390-407.

[4] Láng I., Csete L., Jolánkai M.: Climate change and Hungary: mitigating the hazard and preparing for the impacts (The "VAHAVA" Report), Szaktudás Kiadó Ház, Budapest, 2007.

[5] Sun, G., Alstad, K., Chen, J., Chen, S., Ford, C. R., Lin, G. et al.: A general predictive model for estimating monthly ecosystem evapotranspiration. Ecohydrology, 4 (2011), 245-255.

[6] Bytnerowicz, A., Omasa, K., Paolett, E.: Integrated effects of air pollution and climate change on forests: A northern hemisphere perspective, Environmental Pollution 147 (2007) 438-445.

[7] Mátyás CS.: Ecological challenges of climate change in Europe's continental, droughtthreatened Southeast In: P Y Groisman, S V Ivanov(eds.): Regional aspects of climateterrestrial-hydrologic interactions in non-boreal Eastern Europe. 278 p. Berlin: SpringerVerlag, 2009. pp. 35-46. (NATO Science for Peace and Security Series).

[8] Mátyás CS.: Will our forests really migrate due to climate change? (Valójában vándorolni fognak-e erdeink a klímaváltozás következtében?) (in Hungarian) Erdészeti Lapok 143, (2008), 18-20

[9] Wang, S., Fu, B., He, C.-S., Sun, G. and Gao, G.-Y.: A comparative analysis of forest cover and catchment water yield relationships in northern China. Forest Ecology and Management, 262, (2011), 1189-1198.

[10] Várallyay GY.: Role of soil multifunctionality in future sustainable agricultural development. Acta Agronomica Hung. 51, (2003), 109-124. 
[11] Federer, C.A., Vörösmarty C., Fekete B.: Sensitivity of annual evaporation to soil and root properties in two models of contrasting complexity. Journal of Hydrometeorology 4,(2003), 1276-1290.

[12] IPCC Special Report on Emissions Scenarios, https://ipcc.ch/pdf/specialreports/spm/sres-en.pdf (download 2018. 12. 10.).

[13] Harrison R. G., Jones C. D., Hughes J. K.: Competing roles of rising CO2 and climate change in the contemporary European carbon balance. Biogeosciences 2008,5, 1-10.

[14] Olesen, J. E., Trnka, M., Kersebaum, K. C., Skjelvåg, A. O., Seguie, B., Peltonen-Sainio, P., Rossi, F., Kozyra, J. and Micale, F.: Impacts and adaptation of European crop production systems to climate change. European Journal of Agronomy 34, (2011), 96112.

[15] Henseler, M., Wirsig, A., Krimly, T., Dabbert, S.: The influence of climate change, technological progress and political change on agricultural land use: calculated scenarios for the Upper Danube Catchment area. German J Agric Econ 2008, 57, 207-219 (Agrarwirtschaft).

[16] National Adaptation Geoinformation System to Agriculture, http://nakfo.mbfsz.gov.hu/hu/node/63 (download 2018 12. 7.)

[17] National Forest Strategy 2016-2030, Földmüvelésügyi Minisztérium Erdészeti és Vadgazdálkodási Főosztálya, September 2016.

[18] NÉS-2 The Second Climate Change Strategy of Hungary (NCCS-2), http://www.kormany.hu/download/f/6a/f0000/N\%C3\%89S_2_strat\%C3\%A9gia_2017 02_27.pdf (download: 2018. 12. 21.) 